\title{
Vertical greenery systems for energy savings in buildings: A comparative study between green walls and green facades
}

\author{
Julià Coma a , Gabriel Pérez ${ }^{\mathrm{a},{ }^{*}}$, Alvaro de Gracia ${ }^{\mathrm{b}}$, Silvia Burés ${ }^{\mathrm{c}}$, Miguel Urrestarazu ${ }^{\mathrm{d}}$, \\ Luisa F. Cabeza ${ }^{\text {a }}$ \\ a GREA Innovació Concurrent, Edifici CREA, Universitat de Lleida, Pere de Cabrera s/n, 25001, Lleida, Spain \\ b Departament d'Enginyeria Mecanica, Universitat Rovira i Virgili, Av. Països Catalans 26, 7 43007, Tarragona, Spain \\ ${ }^{\mathrm{c}}$ Buresinnova S.A., Barcelona, Spain \\ d Departamento de Agronomía, Universidad de Almería, Almería, 04120, Spain
}

\section{A R T I C L E I N F O}

\section{Article history:}

Received 23 June 2016

Received in revised form

2 November 2016

Accepted 5 November 2016

Available online 8 November 2016

\section{Keywords:}

Vertical greenery systems

Green wall

Green facade

Energy savings

Green infrastructure

Ecosystem services

\begin{abstract}
A B S T R A C T
During the last decade, vertical greenery systems are increasing their presence in building designs, providing several urban ecosystem services. One of them is the potential to provide energy savings in buildings, which develops an important role, however, data about its performance during winter periods is still scarce. Therefore, the main objective of this paper is to compare at real scale the thermal performance of two different vertical greenery systems implemented in experimental houses-like cubicles for both cooling and heating periods. A double-skin green facade has been installed in the first cubicle that uses deciduous creeper plants, while the second one is designed with green walls made with evergreen species. Finally, a third identical cubicle without any green coverage is used as reference. Two different types of experiments have been carried out to test the performance of the house like-cubicles. One consists of controlling the internal ambient temperature providing heating or cooling to maintain the desired comfort conditions. On the other hand, to study the thermal response of the construction system, the heating, ventilation and air conditioning system was disconnected and the cubicles were tested under free floating condition. First results showed a high potential for energy savings during cooling season for green wall $(58.9 \%)$ and double-skin green facade $(33.8 \%)$ in comparison to the reference system. On the other hand, for heating periods no extra energy consumption was observed for evergreen system.
\end{abstract}

() 2016 Elsevier Ltd. All rights reserved.

\section{Introduction}

In recent years, new design trends are being applied in architecture and construction fields so that environmental and social criteria are considered at the same level of aesthetics, economic and functional ones.

These contemporary design criteria provide a new social conception of the building sector. Moreover, they also enhance the quality of the next generation of buildings by introducing environmental concepts that consider the whole life of the materials, energy and water consumed throughout the construction, operational and end of life processes of a building [1].

\footnotetext{
* Corresponding author.

E-mail addresses: gperez@diei.udl.cat (G. Pérez), sbures@buresinnova.com (S. Burés), mgavilan@ual.es (M. Urrestarazu).
}

Within this context, the concept of Urban Green Infrastructure has been defined as a set of man-made elements which provides multiple ecosystem services at building and urban scales. Among these functions, building energy saving as well as the reduction of urban heat island effect are stand out. Some of the most innovative and interesting solutions for this purpose are green roofs (GR) and vertical greenery systems (VGS) for buildings [2]. From these two construction typologies, GR and VGS, the second ones have possibly higher potential for improvement [3].

Recent studies about the use of VGS highlight that there are four key factors that influence their operation as passive system for energy savings in buildings [4]:

- First, the sort of construction system used to place plants on the building facades (classification of VGS). Regarding to the classification of these systems it is important to take into consideration the great differences between construction systems, 